\title{
Pelaksanaan Timbangan dalam Jual Beli Ayam Potong di Tinjau Dari Perspektif Ekonomi Islam (Studi Kasus di Pasar Raya Amahami Kota Bima)
}

\author{
Sri Wahyunti ${ }^{1^{*}}$, Eka Setyani ${ }^{2}$ \\ ${ }^{1,2)}$ Institut Agama Islam Muhammadiyah Bima \\ *Corresponding Author: sri.wahyunti@gmail.com
}

\begin{abstract}
ABSTRAK - Penelitian ini adalah penelitian kualitatif dengan pendekatan deskriptif. Dengan tekhnik pengumpulan data observasi, dokumentasi, dan wawancara. Penelit melakukan pengecekan ulang terhadap data yang diperoleh dan menggunakan teknik triangulasi. Setelah itu, menganalisisnya melalui reduksi data, penyajian data dan penarikan kesimpulan. Hasil penelitian ini dapat diketahui bahwa penerapan Ekonomi Islam terhadap praktek timbangan jual beli ayam potong di Pasar Raya Amahami belum diterapkan secara efektif. Karena ada beberapa pedagang yang belum sempurna dalam menggunakan timbangannya dalam menjual ayam potong.
\end{abstract}

Kata Kunci - Jual Beli; Pelaksanaan Timbangan; Ekonomi Islam

\begin{abstract}
This research is a qualitative research with a descriptive approach. With data collection techniques observation, documentation, and interviews. Researchers re-checked the data obtained and used triangulation techniques. After that, analyze it through data reduction, data presentation and drawing conclusions. The results of this study can be seen that the application of an Islamic economic perspective to the practice of buying and selling slaughtered chicken in the Amahami market has not been implemented effectively. Because there are some traders who are not perfect in using their scales in selling chicken pieces.
\end{abstract}

Keywords - Buying and Selling; implementation of scales; Islamic Economic

\section{PENDAHULUAN}

Pasar adalah tempat dimana bertemunya pembeli dan penjual dalam melakukan transaksi untuk memperoleh suatu barang dan jasa. Pasar merupakan salah satu sumber pendapatan asli daerah (PAD). Pendapatan asli daerah (PAD) adalah hak dari Pemerintah Daerah yang dapat diakui sebagai penambah nilai kekayaan dalam suatu periode pemerintahan yang bersangkutan. Pasar Raya Amahami adalah pasar tradisonal yang di kelola oleh pemerintah Kota Bima. Pasar Raya Amahami merupakan pasar tradisonal yang menjual seluruh kebutuhan rumah tangga masyarakat mulai dari peralatan rumah tangga sampai kebutuhan bumbu dapur. Demi memenuhi kebutuhan dan kenyaman konsumen maka pengelola Pasar Raya Amahami membagi beberapa blok penjualan seperti blok ikan, blok sayuran, blok buah-buahan, blok daging dan blok lainnya. 
Perdagangan dalam jual beli selalu dihubungkan dengan nilai-nilai moral, sehingga semua transasksi bisnis yang bertentangan dengan kebajikan tidaklah bersifat Islami. Sebagai contoh, setiap pedagang atau penjual harus menyatakan kepada pembeli bahwa barang tersebut layak dipakai dan tidak cacat atau seandainya ada cacat maka itu pun harus diungkapkan dengan jelas dengan kata lain harus adanya keterbukaan dari penjual. Dan sebagian besar praktek perdagangan atau jual beli yang dilakukan hampir menerapkan sistem timbangan dan takaran.

Timbangan merupakan jenis alat pengukuran yang paling umum digunakan dalam jual beli. Kegunaannya untuk mengukur massa suatu benda dengan sama berat sehingga tidak berat sebelah. Beratnya suatu benda diukur dari besarnya nominal angka yang tertera pada timbangan. Jenis timbangan beragam-ragam, kegunaannya sesuai dengan kebutuhan atau bentuk barang yang ingin ditimbang. ${ }^{1}$ Bahkan, beberapa barang yang biasanya dimeter atau dihitung satuannya juga diperjualbelikan dengan timbangan atau takaran, misalnya kain kiloan, telor kiloan, ayam/daging kiloan, dan lain sebagainya. Namun dalam kenyataan tidak semua pedagang berlaku jujur dalam menimbang, menakar atau mengukur. ${ }^{2}$

Dalam transaksi jual beli ayam potong, kita dianjurkan untuk menyempurnakan takaran maupun timbangan dan tidak dibenarkan mengurangi hak orang lain. Seseorang tidak dibenarkan menakar dengan dua takaran atau menimbang dengan dua timbangan. Membeda-bedakan timbangan yang menguntungkan diri sendiri maupun orang yang disenanginya, dan timbangan untuk orang lain. Untuk diri sendiri dan pengikutnya dia penuhi timbangannya, sedangkan untuk orang lain timbangannya dikurangi. Karena dengan menyerahkan atau menerima sesuatu yang takarannya atau timbangannya tidak sempurna, dikurangi atau dilebihkan daripada semestinya, menyebabkan adanya pihak yang dirugikan disamping pihak yang memperoleh keuntungan yang bukan menjadi kaya. Sikap yang demikian akan menghilangkan sumber keberkahan, karena merugikan atau menipu orang lain yang didalamnya terjadi eksploitasi hak-hak yang tidak dibenarkan dalam Islam.

Berdasarkan hasil wawancara dengan Bpk Sariman, S.H. selaku kepala UPT atau pengelola Pasar Raya Amahami Kota Bima, beliau mengatakan bahwasannya jumlah penjual ayam potong di Pasar Raya Amahami ada

\footnotetext{
1 Hayatul Ichsan, “Tinjauan Hukum Islam Terhadap Praktek Penimbangan dalam Jual Beli Kelapa Sawit", ("Skripsi”, UIN Ar-Raniry, Aceh, 19 November 2018), 12.

${ }^{2}$ Linda Khoirun Nisak, dkk., "Analisis Kecurangan Dalam Takaran Dan Timbangan Oleh Pedagang Ditinjau Dari Fiqih Riba”, (“Skripsi” STAIN, Kediri, 2008), 109.
} 
sebanyak 45 orang, dan ditempatkan di bagian blok daging. Dari jumlah penjual tersebut semuanya menggunakan jual beli dengan menggunakan timbangan. ${ }^{3}$

Kemudian berdasarkan Wawancara dengan salah satu penjual ayam potong mengenai pelaksanaan timbangan ayam potong, beliau mengatakan bahwasannya praktek timbangan yang dilakukan oleh penjual ayam potong yaitu dengan menggunakan timbangan apabila ada pembeli yang membeli $1 \mathrm{~kg}$, maka kami menggunakan anak timbangan yang standar $1 \mathrm{~kg}$ dengan harga jual / kg yaitu 50.000 untuk harga ayam yang baru dan 45.000 untuk harga ayam yang diberi es/lama. ${ }^{4}$ Dan harga tersebut ditentukan oleh penjual tanpa ada campur tangan dari pemerintah. Dan kepala UPT juga bukan penentu harga, karena mereka hanya sebagai pemantau keluar masuk barang. Oleh karena itu, dalam proses timbangan jual beli ayam potong ada yang sepenuhnya tidak menerapkan prinsip kejujuran, masih banyak unsur penipuan dan merugikan orang lain hanya untuk keuntungan pribadi.

Dari hasil wawancara dengan ibu salmah menyatakan bahwa para penjual ayam potong diPasar Raya Amahami Kota Bima dalam melakukan timbangan atau takaran belum sepenuhnya menerapkan prinsip syariah, ini dikarenakan penerapan harga jual tidak ada campur tangan dari pemerintah. Bahkan dalam hal ini pun yang dapat saya lihat, bahwa dalam hal timbangan yang seharusnya antara ayam dan anak timbangan harus memiliki keseimbangan diantara keduanya. Selain itu juga terdapat sebagian penjual yang segera mengangkat ayam atau anak timbangan sebelum timbangan menunjukan arah satuan kilonya. ${ }^{5}$ Dan hal tersebut dapat merugikan pihak pembeli dengan tindakan kecurangan yang dilakukan oleh penjual.

Kemudian berdasarkan hasil observasi yang dilakukan oleh peneliti terkait pelaksanaan timbangan jual beli ayam potong di Pasar Raya Amahami, yang peneliti lihat dalam transaksinya, ada beberapa penjual yang memperhatikan pelanggannya dan ada dari mereka yang sibuk dengan teman sepenjualannya di sebelah sambil melakukan timbangan. Dan saat mereka menimbang ada yang masih mengeluarkan sebagian ayam tersebut disela-sela sebelum mereka mengangkat dan memasukan ayamnya ke dalam plastik. Dalam proses pelayanan yang diberikan oleh setiap penjual berbeda-beda terhadap pembeli.

\footnotetext{
3 Sariman, S.H, Kepala UPT Pasar Raya Amahami, Wawancara, Bima, 29 Mei 2021.

4 Ibu Fatimah, Wawancara, Bima, 29 Mei 2021

${ }^{5}$ Ibu Salmah, Wawancara, Kota Bima, 29 Mei 2021
} 


\section{TINJAUAN PUSTAKA}

\section{Timbangan}

\section{Pengertian Timbangan}

Menurut Prof. Dr. Ali Jumuah, timbangan dan takaran adalah jenis alat pengukuran barang yang paling umum dalam perdagangan dan jual beli. Bahkan, beberapa barang yang biasanya dimeter atau dihitung satuannya juga diperjualbelikan dengan timbangan atau takaran, misalnya kain kiloan, telor kiloan, ayam kiloan, dan lain sebagainya. Namun dalam kenyataan tidak semua pedagang berlaku jujur dalam menimbang, menakar atau mengukur. ${ }^{6}$

Kata “Takaran" dalam Kamus Bahasa Arab, yaitu: mikyal, kayl. Sedangkan kata "Timbangan" dalam Kamus Bahasa Arab yaitu: wazn mizan. Takaran diartikan sebagai proses mengukur untuk mengetahui kadar, berat, atau harga barang tertentu. ${ }^{7}$ Timbangan secara terminologi adalah alat yang dipakai untuk melakukan pengukuran masa suatu benda. Timbangan atau neraca dikategorikan kedalam sistem mekanik dan juga elektronik atau digital. Timbangan atau takaran dalam Islam sudah menjadi kelaziman dalam dunia dagang, dipergunakan berbagai macam ukuran untuk menentukan banyak dan jumlah barang yang ditransaksikan

\section{Jual Beli}

Menurut Shobirin Jual beli dalam istilah fiqh disebut dengan al-bai' yang berarti menjual, mengganti, dan menukar sesuatu dengan sesuatu yang lain. Lafal al bai' dalam bahasa Arab terkadang digunakan untuk pengertian lawannya, yakni kata al-syira' (beli) digunakan dalam pengertian yang sama. Dengan demikian, kata al-bai' berarti jual, tetapi sekaligus juga berarti beli. ${ }^{8}$ Sedangkan menurut istilah yang dimaksud jual beli atau perdagangan adalah:

1. Menukar barang dengan barang atau barang dengan uang dengan jalan melepaskan hak milik dari yang satu kepada yang lain atas dasar saling merelakan.

2. Menurut Syekh Muhammad ibn Qâsim al-Ghazzi Menurut syara, pengertian jual beli yang paling tepat ialah memiliki sesuatu harta (uang) dengan mengganti sesuatu atas dasar izin syara, sekedar memiliki manfaatnya saja yang diperbolehkan syara untuk selamanya yang demikian itu harus dengan melalui pembayaran yang berupa uang.

${ }^{6}$ Linda Khoirun Nisak, dkk., “Analisis Kecurangan. 109.

${ }^{7}$ Hayatul Ichsan, Tinjauan Hukum 14.

8 Shobirin, "Jual Beli Dalam Pandangan Islam." Jurnal Beli dan Manajemen Islam, No.2, Volume III (Desember, 2015), 240. 
3. Menurut Imam Taqiyuddin dalam kitab Kiffayatul alAkhyar Saling tukar harta, saling menerima, dapat dikelola (tasharruf) dengan ijab qobul, dengan cara yang sesuai dengan syara.

4. Syeikh Zakaria al Anshari dalam kitabnya fath Al-Wahab Tukar-menukar benda lain dengan cara yang khusus (dibolehkan).

5. Menurut Sayyid Sabiq dalam Kitabnya Fiqh Sunnah Penukaran benda dengan benda lain dengan jalan saling atau memindahkan hak milik dengan ada penggantinya dengan cara yang diperbolehkan.

6. Ada sebagian ulama memberikan pemaknaan tentang jual beli (bisnis), diantaranya; ulamak Hanafiyah "Jual beli adalah pertukaran harta dengan harta (benda) berdasarkan cara khusus (yang di bolehkan) syara' yang disepakati". Menurut Imam nawawi dalam al-majmu' mengatakan "Jual beli adalah pertukaran harta dengan harta untuk kepemilikan". Menukar barang dengan barang atau barang dengan uang dengan jalan melepaskan hak milik atas dasar saling merelakan. ${ }^{9}$

\section{Prinsip-Prinsip Jual Beli dalam Ekonomi Islam}

Prinsip-prinsip ekonomi Islam yang merupakan bangunan ekonomi Islam disasarkan atas lima nilai universal yakni: tauhid (keimanan), 'adl (keadilan), nubuwwah (kenabian), khilafah (pemerintahan) dan ma'ad (hasil). Kelima hasil ini menjadi dasar inspirasi untuk menyusun teori-teori ekonomi Islam. Dari nilai dan prinsip tersebut, dibangunlah konsep yang memayungi kesemuanya, yakni konsep akhlak. Akhlak menempati posisi puncak, karena inilah yang menjadi tujuan Islam dan dakwah para Nabi, yakni untuk menyempurnakan akhlak manusia. Beberapa prinsip dari ekonomi Islam yang ditawarkan oleh Muhammad Djakfar yaitu sebagai berikut: ${ }^{10}$

1. Menjual barang yang baik mutunya

2. Jujur dalam takaran

3. Mengutamakan keadilan dan tanggung jawab dalam berniaga

\section{METODOLOGI PENELITIAN}

Penelitian ini menggunakan metode kualitatif deskriptif. Metodelogi kualitatif sebagai prosedur penelitian yang menghasilkan data deskriptif berupa kata-kata tertulis atau lisan dari orang-orang dan perilaku yang dapat diamati. ${ }^{11}$ Jenis penelitian yang dilakukan oleh peneliti merupakan jenis penelitian

9 Ibid, 242.

${ }^{10}$ Ira Hasti Priyadi, dkk, “Edukasi Prinsip-prinsip Ekonomi Syariah kepada Pedagang dan Pelaku Usaha Mikro Kecil dan Menengah, Journal of community Engagement, No. 1, Volume 2, (Juni 2020), 22.

11Ahmad Usman, Mari Belajar Meneliti, (Yogyakarta: Genta Press, 2008), 229. 
lapangan dengan menggunakan metode kualitatif deskriptif. Penelitian lapangan ini pada hakikatnya merupakan metode untuk menemukan secara spesifik realistas tentang apa yang sedang terjadi di tengah-tengah kehidupan masyarakat.

Sumber data yang digunakan menggunakan data primer da sekunder. Data primer adalah sumber data yang langsung memberikan data kepada pengumpul data. ${ }^{12}$ Data tersebut diperoleh dari keterangan orang-orang yang berhubungan dengan penelitian. Adapun sumber data primer dalam penelitian ini diperoleh dengan wawancara langsung dengan pihak pengelola pasar, penjual dan pembeli ayam potong. Sedangkan data sekunder merupakan sumber yang tidak langsung memberikan data kepada pengumpul data, misalnya lewat orang lain atau lewat dokumen. ${ }^{13}$ Sedangkan data yang termasuk data sekunder dalam penelitian ini adalah data yang berasal dari literatur yang berkenaan dengan Pelaksanaan Timbangan Dalam Jual Beli Ayam Potong Di Pasar Raya Amahami Kota Bima Di Tinjau Dari Perspektif Ekonomi Islam.

Pengumpulan data diperoleh dengan cara observasi, wawancara, dan dokumentasi yang diperkuat melalui instrument penelitian ketiga point ini. Adapun analisis datanya melalui tahapan; pengumpulan data, reduksi data, penyajian data, dan penarikan kesimpulan. Selanjutnya, diuji kredibilitas data melalui perpanjangan pengamatan, triangulasi dan menggunakan bahan referensi.

\section{HASIL DAN PEMBAHASAN}

\section{Penyajian Data}

Untuk lebih jelasnya maka di peroleh hasil wawancara dengan 5 orang penjual ayam potong yang menggunakan timbangan dalam transaksi jual beli mereka di Pasar Raya Amahami Kota Bima. Berikut adalah wawancara pertama yang peneliti lakukan dengan ibu Purwaningsih:

"Saya sudah 5 tahun berdagang ayam potong, dalam penggunaan timbangan saya menggunakannya seperti biasanya, jenis timbangan yang saya gunakan merk CK. Ayam yang bisa terjual rata-rata dalam sehari berjumlah 100 ekor, saya mendapatkan ayam dengan membeli dari orang lain, dan pemerintah datang untuk mengecek timbangan setahun sekali."14

\footnotetext{
12 Hardani Dkk, Metode Penelitian Kualitatif Dan Kuantitatif, (Yogyakarta: CV Pustaka Ilmu Group, 2020), 210.

${ }^{13}$ Ibid., 120.

${ }^{14}$ Ibu Purwaningsih, Wawancara, 12 Mei 2021
} 
Wawancara dengan Bapak Anton:

"saya berjualan ayam potong kurang lebih sudah 5 tahun, dalam menggunakan timbangan untuk menjual ayam potong saya menimbang sperti orang yang secara normal, jika ada yang membeli $1 \mathrm{~kg}$ saya timbang sesuai takaran $1 \mathrm{~kg}$, merk timbangan yang saya gunakan merupakan timbangan meja CK, dalam sehari saya biasanya dapat menjual kurang lebih 80 ekor ayam namun kalua dalam keadaan sekarang sedang sepi karena sudah pndah tempat, saya mendapat ayam beli dari orang lain, pemerintah biasanya datang mengecek timbangan kami para pedagang setahun sekali."15

Secara umum, jawaban penjual atas pertanyaan peneliti relative sama (ibu Sulatri, ${ }^{16}$ ibu Fatimah ${ }^{17}$ dan bapak Jainudin ${ }^{18}$ ). Bahwa dalam penggunaan timbangan mereka menggunakannya dengan cara yang normal. Tidak ada indikasi kecurangan berdasarkan penyaampaian mereka.

Selain mewawancarai penjual peneliti juga mewawancarai pembeli ayam potong yang ada di Pasar Raya Amahami, berikut adalah hasil wawancara peneliti dengan pembeli:

Wawancara dengan Bapak Agus Sarweda:

"Saya sering membeli ayam potong di Pasar Raya Amahami, saya lebih sering membeli di satu tempat karena pelayanan yang di lakukan cukup baik dan memang sudah kenal, kalau penjelasan mengenai kualitas kita lihat sendiri dan tidak ada penjelasan, untuk penimbangan terkadang penjual langsung menghitung saat timbangannya masih gerak dan sering kali mengurangi ayam yang sudah pas ditimbanganya kemudian langsung di masukan ke dalam plastik". 19

Wawancara dengan Ibu Wasti:

"Saya jarang membeli ayam potong di pasar kalau sedang butuh saja saya beli, saya membeli ayam potong di satu tempat penjual saja karena memang sudah biasa, pelayanannya cukup bagus, tidak ada penjelasan yang di berikan oleh penjual mengenai kualitas ayam yang di jual, dan saat penjual menimbang ayam mereka langsung menghitung saat timbangannya masih bergerak ke atas." 20

Selanjutnya wawancara dengan pembeli atas nama Ibu Saliama:

“Saya membeli ayam potong di Pasar Amahami jarang, baru dua kali sampai tiga kali, dan setiap saya membeli selalu ke penjual yang berbeda-beda,

15 Bapak Anton, Wawancara, 12 Mei 2021

16 Ibu Sulastri, Wawancara, 12 Mei 2021

17 Ibu Fatimah, Wawancara, 12 Mei 2021

18 Bapak Jainudin, Wawancara, 12 Mei 2021

19 Bapak Agus Sarweda, Wawancara, 1 Juni 2021

20 Ibu Wasti, Wawancara, 23 September 2021 
mengenai pelayanannya lumayan baik, dan sebelum saya membeli saya akan bertanya terkait kualitas ayamnya baru kemudian penjual menjelaskan kualitasnya, dan pada saat mereka menimbang terkadang saat timbangannya masih goyang ke atas lalu dihitung oleh penjual."21

\section{Analisis Data}

Dalam transaksi jual beli dengan menggunakan timbangan, dianjurkan untuk menyempurnakan takaran maupun timbangan dan tidak dibenarkan mengurangi hak orang lain. Menyerahkan atau menerima sesuatu yang takarannya atau timbangannya tidak sempurna, dikurangi atau dilebihkan daripada semestinya, menyebabkan adanya pihak yang dirugikan disamping pihak yang memperoleh keuntungan. Sikap yang demikian akan menghilangkan sumber keberkahan, karena merugikan atau menipu orang lain yang didalamnya tidak dibenarkan dalam Islam. Sebagaimana Allah SWT berfirman dalam Qur'an Surah Al-An'am ayat 152.

Terjemahan: dan janganlah kamu dekati harta anak yatim, kecuali dengan cara yang lebih bermanfaat, hingga sampai ia dewasa. dan sempurnakanlah takaran dan timbangan dengan adil. Kami tidak memikulkan beban kepada sesorang melainkan sekedar kesanggupannya. dan apabila kamu berkata, Maka hendaklah kamu Berlaku adil, Kendatipun ia adalah kerabat(mu), dan penuhilah janji Allah, yang demikian itu diperintahkan Allah kepadamu agar kamu ingat (QS.Al-An'am: 152). ${ }^{22}$

Berdasarkan wawancara yang dilakukan oleh peneliti dengan para penjual ayam potong di atas dapat di simpulkan kalau dalam penggunaan timbangan yang dilakukan oleh si penjual cenderung normal. Analisis data menyipulkan bahwa tidak ada yang melakukan kecurangan dalam menimbang ayam potong. Namun berdasarkan hasil wawancara dengan salah satu pembeli ayam potong di Pasar Raya Amahami Kota Bima yaitu bapak Agus Sarweda, kegiatan penimbangan yang dilakukan oleh penjual ayam potong yang ada di Pasar Raya Amahami cenderung umum dan terbuka, namun kadang kala saat mereka menimbang mereka jarang memperhatikan saat timbangan dimulai, kadang mereka melihat sekilas dan saat timbangan sudah menunjukan keseimbangan masih ada yang mengurangi ayamnya dan kemudian langsung di masukan ke dalam plastik, dan beliau menerangkan bahwa penjual tidak menjelaskan kualitas ayam yang dijual. Begitupun wawancara dengan ibu Wasti, dan ibu Saliama, yang merupakan pembeli ayam potong. Dapat di simpulkan bahwasannya pernyataan yang ibu-ibu ini berikan sama dengan pernyataan bapak Agus Sarweda dimana penggunaan timbangan yang dilakukan masih

${ }^{21}$ Ibu Saliama, Wawancara, 23 September 2021

22 QS.Al-An'am (6): 152. 
bergerak namun ayam langsung dimasukkan ke dalam pelastik. Yang artinya para penjual timbangan tidak sesuai dengan ketetapan penggunaan timbangan yang seharusnya.

Berdasarkan permasalahan di atas dapat di simpulkan bahwasannya pelaksanaan timbangan ayam potong yang dilakukan oleh penjual di Pasar Raya Amahami Kota Bima belum secara penuh menerapkan prinsip syariah. Sebagaimana firman allah SWT dalam Qur'an surah Al-Isra ayat 35

Terjemahan: "dan sempurnakanlah takaran apabila kamu menakar, dan timbanglah dengan neraca yang benar. Itulah yang lebih utama (bagimu) dan lebih baik akibatnya." (Q.S Al-Israa:35)

\section{Pembahasan}

Pelaksanaan Timbangan dalam Jual Beli Ayam Potong yang dilakukan oleh Pedagang di Pasar Raya Amahami

Dalam melaksanakan jual beli ayam potong, penjual di Pasar Raya Amahami melakukan penimbangan ayam potong yang mereka jual sesuai dengan anjuran yang seharusnya dengan menggunakan jenis timbangan Dacing yang bermerk CK dan juga SKN. Dalam pelaksanaan timbangan ayam potong apabila ada pembeli yang membeli $1 \mathrm{~kg}$ maka penjual menimbang dengan menggunakan anak dacing yang untuk ukuran $1 \mathrm{~kg}$, dan juga tersedia anak dacing yang untuk $1 / 2 \mathrm{~kg}$. Sesuai dengan ketetapan anjuran pemerintah yang berlaku, pemeriksaan timbangan rutin dilakukan oleh pemerintah yaitu setahun sekali. Berdasarkan peraturan yang mengatur tentang timbangan, maka dibuatkan Undang-undang pelaksanaan Timbangan di Indonesia Nomor 2 tahun 1981 tentang metrologi legal.

Sesuai dengan pernyataan salah satu penjual yaitu ibu Purwaningsih, "saya menggunakan timbangan yang seperti penjual lainnya, yaitu menggunakan timbangan dacing yang ditera dalam 1 kali setahun dan menimbang ayam potong dengan normal." 23

Berdasarkan pernyataan penjual diatas menyatakan bahwasanya penggunaan timbangan yang ada di Pasar Amahami sesuai dengan standar penggunaan. Namun berbeda hal dengan pernyataan yang diberikan oleh pembeli ayam potong di Pasar Amahami yaitu dengan Ibu Saliama. Beliau mengatakan bahwasannya saat penjual menimbang ayam potong masih goyang ke atas langsung dihitung oleh penjual.

Walaupun timbangan penjual sudah ditera atau diperiksa oleh pemerintah, namun cara yang dilakukan oleh penjual ayam potong dalam pelaksanaan Jam:09:00.

23 Ibu Purwaningsih selaku penjual ayam potong, Wawancara, Bima, 12 Mei 2021, 
timbangan yang dilakukan di Pasar Amahami Kota Bima masih belum sepenuhnya menerapkan prinsip sesuai dengan perspektif ekonomi Islam.

\section{Perspektif Ekonomi Islam terhadap Praktek Timbangan Jual Beli Ayam Potong di Pasar Raya Amahami.}

Praktek Timbangan Ayam Potong yang dilakukan oleh penjual di Pasar Raya Amahami belum sepenuhnya diterapkan dan sesuai dengan Perspektif Ekonomi Islam. Dan itu berdasarkan Pernyataan dari salah satu pembeli yaitu dengan Bpk Agus Sarweda. Beliau menyatakan bahwasannya kegiatan penimbangan yang dilakukan oleh penjual ayam potong yang ada di Pasar Raya Amahami cenderung umum dan terbuka, namun kadang kala saat mereka menimbang mereka jarang memperhatikan saat timbangan dimulai, kadang mereka melihat sekilas dan saat timbangan sudah menunjukan keseimbangan masih ada yang mengurangi ayamnya dan kemudian langsung di masukan ke dalam plastik, dan beliau menerangkan bahwa penjual tidak menjelaskan kualitas ayam yang dijual.

Pernyataan mengenai konsumen atau pembeli yang merasa tertipu bukan hal baru lagi. Sering terungkap barang yang dibeli tidak sesuai dengan yang ditawarkan atau di iklankan. Atau ukuran barang tidak sesuai dengan yang disebutkan atau yang disepakati. Lebih sering lagi timbangan yang tidak sesuai dengan barang yang dibayar. Kalau kita cermat dan sedikit mau repot, kita dapat mencoba memeriksa kembali timbangan kemasan barang misalnya gula atau beras yang kita beli. Kemungkinan berat yang berlabel $1 \mathrm{~kg}$ hanya berisi 0,9 kg.

Kita juga sering menyaksikan atau mungkin mengalami rasa tidak puas karena pelayanan pada kita sebagai konsumen tidak seperti yang kita harapkan. Dalam prinsip ekonomi Islam menurut Muhammad Djakfar ada beberapa hal yang harus diperhatikan oleh para pedagang yaitu antara lain:

1. Menjual Barang Yang Baik Mutunya

Penjual harus transparansi dalam menjual barangnnya kepada pembeli, baik dengan kualitas barangnya yang kurang baik, baik dan tidak baik untuk di perjualbelikan, semua itu harus diketahui oleh pembeli. tetapi sebagian dari penjual ada yang menyembunyikan kecacatan yang ada dalam barang tersebut dengan maksud agar transaksi dapat berjalan lancer. Padahal menyembunyikan mutu sama halnya dengan berbuat curang dan bohong.

2. Jujur dalam Takaran

Perilaku jujur dan tidak jujur tidak dapat dipisahkan dari kehidupan manusia sehari-hari. Terjadinya korupsi, penyalahgunaan kekuasaan, penimbunan barang, dan juga menjual sesuatu yang tidak baik zatnya merupakan implementasi dari sebagian prilaku ketidakjujuram. Dan 
kecurangan dalam kasus timbangan jual beli ayam potong didalamnya terkadang berat ayam potong tidak sesuai dengan berat yang ditimbang.

Pengurangan timbangan adalah pangkal mula rusaknya perdagangan dan hilangnya kepercayaan seseorang. Sifat-sifat kotor merupakan sifat umum yang dimiliki manusia ketika memasuki dunia bisnis. Mereka tidak terikat ruang dan waktu karena merupakan karakter mendasar manusia. Karena itu Islam membenarkan jalan yang terbaik untuk menyelesaikannya yaitu dengan mengikuti pesan-pesan Nabi Saw. Yaitu sifat-sifat yang terpuji. Jika pedagang menerapkan sifat terpuji maka hal ini menunjukan bahwa masyarakat pedagang khususnya dan masyarakat pada umumnya.

Adapun kenyataan yang terjadi di Pasar Raya Amahami dalam hal timbangan, penjualan ayam potong oleh pedagang belum menerapkan ajaran Islam, mereka pedagang mengurangi timbangan dan merugikan si pembeli dalam timbangan, mereka menimbang timbanganya masih goyang dan timbangan itu belum sama berat mereka langsung menghitung. Suatu pelaksanaan timbangan yang tidak adil dan dalam hal ini dapat merugikan si pembeli. Rasulullah mengajarkan agar para pedagang senantiasa bersikap adil, baik, kerjasama, amanah, tawakal, qana'ah, sabar dan tabah. Sebaliknya beliau juga menasihati agar pedagang meninggalkan sifat kotor perdagangan yang hanya memberikan keuntungan sesa'at, tetapi merugikan diri sendiri duniawi dan ukhrowi. Akibatnya kredibilitas hilang, pelanggan lari, dan kesempatan berikutnya sempit.

3. Mengutamakan Keadilan dan Tanggung Jawab dalam Berniaga

Keadilan merupakan pengakuan dan perlakuan yang seimbang antara hak dan kewajiban. Misalnya, jika kita mengakui hak hidup maka kita juga berkewajiban untuk mempertahankan hak hidup itu dengan bekerja keras tanpa merugikan orang lain karena orang lain juga memiliki hak hidup yang sama dengan kita.

Pedagang juga bertanggung jawab sebagai pemegang amanat dari Allah untuk manusia, Allah memberikan amanat kepada pedagang untuk berdagang secara jujur dan benar.

Agar supaya tidak terjadi penimbangan yang curang sebaiknya antara penjual dan pembeli harus saling terjadi kesepakatan. Dan juga diharapkan agar pedagang supaya selalu memakai timbangan yang sudah ditera dan ditera ulang yang telah disebutkan sebelumnya didalam Undang-undang di Indonesia. Dengan demikian cara begini hendaknya diharapkan tidak terjadi kecurangan dalam penimbangan. 


\section{KESIMPULAN}

Berdasarkan hasil penelitian yang dilakukan di pasar raya Amahami terkait dengan pelaksanaan timbangan dalam jual beli ayam potong yang ada di pasar raya Aamahami Kota | Bima, maka dapat disimpulkan bahwa:

1. Proses pelaksanaan timbangan yang dilakukan oleh para pedagang ayam potong yang ada di pasar raya Amahami Kota Bima kurang memahami dan bahkan tidak mengetahui cara penggunaan timbangan yang benar secara ekonomi Islam, para pedagang hanya memikirkan keuntungan saja tanpa memikirkan kepuasan pembeli.

2. Penerapan ekonomi Islam dalam praktek timbangan jual beli ayam potong di Pasar Raya Amahami Kota Bima belum diterapkan secara efektif. Karena ada beberapa pedagang yang belum sempurna dalam menggunakan timbangannya dalam menjual ayam potong.

\section{DAFTAR PUSTAKA}

Ahmad Usman, Mari Belajar Meneliti, (Yogyakarta: Genta Press, 2008)

Hardani Dkk, Metode Penelitian Kualitatif Dan Kuantitatif, (Yogyakarta: CV Pustaka Ilmu Group, 2020)

Hayatul Ichsan, “Tinjauan Hukum Islam Terhadap Praktek Penimbangan dalam Jual Beli Kelapa Sawit”, (“Skripsi”, UIN Ar-Raniry, Aceh, 19 November 2018)

Ira hasti Priyadi, dkk, "Edukasi Prinsip-prinsip Ekonomi Syariah kepada Pedagang dan Pelaku

Linda Khoirun Nisak, dkk., "Analisis Kecurangan Dalam Takaran Dan Timbangan Oleh Pedagang Ditinjau Dari Fiqih Riba", ("Skripsi" Stain, Kediri, 2008)

Sariman, S.H, Kepala UPT Pasar Raya Amahami, Wawancara, Bima, 29 Mei 2021. Shobirin, "Jual Beli Dalam Pandangan Islam." Jurnal Beli dan Manajemen Islam, No.2, Volume III (Desember, 2015)

Usaha Mikro Kecil dan Menengah "Journal of community Engagement, No. 1, Volume 2, (Juni 2020) 